\title{
The Influence of Impulsive Personality Traits and Store Environment on Impulse Buying of Consumer in Karachi
}

\author{
Sana Hussain ${ }^{1} \&$ Danish Ahmed Siddiqui ${ }^{1}$ \\ ${ }^{1}$ Karachi University Business School, University of Karachi, Pakistan \\ Correspondence: Sana Hussain, Research Scholar, Karachi University Business School, University of Karachi, \\ Pakistan.
}

Received: March 16, 2019

Accepted: April 8, 2019

Online Published: April 10, 2019

doi:10.5430/ijba.v10n3p50

URL: https://doi.org/10.5430/ijba.v10n3p50

\begin{abstract}
This study was aimed to understand and assess the role of store environment, impulsive buying personality traits, impulsive buying tendency, and urge to buy on impulsive buying. Data was collected from 250 respondents and analyzed using Structural Equation Modeling technique, findings suggested that impulse buying was positively associated with impulse buying tendency, impulsively personality trait and urge to buy. The most important finding of the study is the insignificant effect of store environment on consumers that are instinctive buyers. The study also suggests that impulsive traits of the consumer directly lead to impulse buying. It actually don't need some drive such as store environment that would stimulate their impulse buying tendency. However, this study didn't find any effect of demographic variables (gender and income) on impulse buying tendency. The overall store environment has insignificant effect on consumer impulse purchase but different attributes such as cleanliness and arrangement of product has relative impact on impulse buying that's why the retailers should focus on store environment elements such as crowd, sales employee, entertainment, lighting, aroma and display etc. to stimulate impulse buying. This study confirmed the role of personality in encouraging impulse buying at retail outlets. Marketers should identify ways to reach out open ended and extrovert people to target their promotional offers.
\end{abstract}

Keywords: impulse buying, impulsive buying behavior, ward store environment, impulse buying tendency, impulsive buying personality traits, urge to buy, structural equation modeling

\section{Introduction}

\subsection{Background}

Impulse buying is often defined as a spur-of-the-moment purchase or taking ownership of the product/goods or services without any deeper thinking (Thompson \& Prendergast, 2015). People who normally get emotionally attached to the product very quickly and usually are the ones who incline to be pleased with the products or goods on the spot. It is not concluded that impulse shopping always ends up with the satisfaction because many times shoppers regret taking such a quick decision and wasting their money over it (Zhou \& Gu, 2015).

Marketing managers have been admitting the importance of impulse buying. In fact, several researches in the west have postulated that around 50\%-70\% of consumers buying decisions in supermarkets involve impulsive buying. Studies like Bellenger, Robertson, and Hirschman (1978), Dawson and Kim (2010) and, Heilman, Nakamoto, and Rao, (2002) have prominent that this could be around $80 \%$ in some product types. Research conducted by Coca Cola found that 50\% of grocery item purchases account for impulse buying (CNBC, 2009).As per Point-of-Purchase Advertising International, 76\% of all shopping decisions in the stores are unplanned (POPAI, 2012). Though it is exhibited in distinctive ways, subject to individual variances like gender, age (e.g., Dittmar, Beattie, \& Friese, 1995, 1996; Kollat \& Willet, 1967; Verplanken\& Herabadi, 2001) or personality trait (Rook \& Fisher, 1995; Youn \& Faber, 2000), impulse purchasing is a widespread worldwide phenomenon. Impulse buying has received remarkable attention in the literature correlated to retail and marketing (Beatty \& Ferrell, 1998; Rook \& Fisher, 1995; Jones et al. 2003; Mohan, Sivakumaran, \& Sharma, 2013; Prashar, Parsad, \& Vijay, 2015). Previous studies on impulse purchasing exposed its many variables, including shopper characteristics, for example: impulse buying tendency (Beatty \& Ferrell, 1998; Rook, 1987; Rook \& Fisher, 1995), product involvement (Jones et al. 2003), and money and time availability as situational factors (Beatty \& Ferrell 1998). 
On the other hand, store environment has appeared as a rising stream of research that measures the impact of its antecedents on shoppers' buying behavior. Mohan, Sivakumaran, and Sharma (2013) demonstrated that store environment and urge to buy have positive relationship.

Small traditional retail stores are slowly and gradually converting into retail chain outlets. The success of the retail chain industry in comparison to traditional retailers is attributed to convenience, choice of goods, huge space and low prices. "Atmosphere is a term that is used to explain our feelings towards the shopping experience which cannot be seen" (Milliman, 1986). Kotler (1973-74) describes the atmosphere as "the theme of the of retail chain outlet that creates specific emotional effects on the buyer that increases his purchasing probability". The consumer purchase intention and decision making process is directly and significantly affected through attractive and impressive atmosphere of retail chain that creates an enjoyable experience among shoppers (Srinivasan \& Srivastava, 2010).

Wakefield \& Baker (1998) verified that the shopper spend more time in the store is stimulated by atmospheric view. The consumer tend to spend more time in specific store and also buy more when he/she is satisfied with the retail environment of the store and pleasant environmental stimuli (Bohl, 2012). The environment has a vast impact on the consumer's emotion and satisfaction. The purchase experience and level of consumer satisfaction is enhanced by the impressive atmosphere of the retail chain outlet (Silva \& Giraldi, 2010).

\subsection{Problem Statement}

Earlier consumers mainly focused on product functions or attributes to opt for a shopping place. Nowadays, consumers ask for added beneficial elements to select retail outlets for their purchases. A satisfying atmosphere of the retail chain outlets is one of those elements which are extremely desired. The store atmosphere has significant role in the success of retail outlet which cannot be neglected (Turley \& Milliman, 2000). However, there is lack of research on impulse buying literature pertaining to the combined impact of store environment and traits of shopping impulsiveness on impulse buying. The latest changes of small traditional retail stores are slowly and gradually converting into retail chain outlets. The success of the retail chain industry in comparison to traditional retailers is attributed to convenience, choice of goods, huge space and low prices.

Impulse buying is shown to have positive association and significant impact on the sales and performance of the supermarkets and retail outlets. In this study, we are interested to know the effect of impulsive personality traits and store environment on impulse buying of consumer. We want to ascertain whether impulsive personality trait and store environment has positive and significant effect on impulse buying or not.

\subsection{Gap Analysis}

Clinical and developmental psychologists, education researchers, and criminologists have studied the general trait of impulsiveness and it has been considered as a basic human trait. Impulse buying may be an indicator of "personality trait" linked with "deficiency of control". Many researchers indicated that deficiency of control or lack of self-control is an important dimension of impulsiveness for observing impulse (Vohs \& Faber, 2007; Youn \& Faber, 2000). (Dania Shakaib Farid and Mazhar Ali, 2018) investigated the role of personality trait namely Openness, Conscientiousness, Extraversion, Agreeableness, and Neuroticism in facilitating an individual to engage in an impulsive buying behavior. It found that personality trait play an important role in encouraging an individual to shop impulsively. The individuals tend to score high in these traits tend to buy things immediately, right on the spot.

Many research studies have been conducted to check the impact of store atmosphere on consumer buying behavior (Russell \& Mehrabian, 1978), but still empirical research on the impact of store atmosphere on the behavior of consumers is limited (Zeynep \& Nilgun, 2011). Researchers concluded that store environment factors like lighting, aroma, sound/music, and existence of sales representative, crowd inside the store, store layout, color and display are main ingredient that can stimulate the consumer desire to purchase spontaneously (Baker et al., 2002; Mattila \& Wirtz, 2008; Rook \& Fisher, 1995). As psychologists mentioned individuals and every human has a unique tendency to act impulsively. Shoppers differ in their impulsive shopping tendency (Beatty \& Ferrell, 1998; Rook, 1987; Rook \& Fisher, 1995; Rook \& Gardner, 1993). Rook (1987) outlines "consumer impulsivity as a lifestyle trait." Previous researchers also demonstrated that shoppers scoring high on IBT prompt more urges to buy and stimulate spur-of-the-moment purchase (Beatty \& Ferrell, 1998; Dawson \& Kim, 2009; Mohan, Sivakumaran, \& Sharma, 2013). Sudies have been done in Pakistan specifically in Karachi related to the impact of store environment on impulse buying (Mazhar ali \& Riaz hussain, 2015) And also the research has done to check the impact of personality traits on impulse buying of consumer (Dania Shakaib Farid and Mazhar Ali, 2018). However, no such effort was made to combine these three. 
Endeavoring to address the above stated gap, this study first time combines the store environment and impulsive personality traits and their effect on impulse buying behavior in Pakistan's region specifically in Karachi. The study also proposes the positive impact of store environment on impulsive buying tendency that leads to urge to buy and finally impulsive purchase. This study also makes an attempt to examine the influence of demographic variables on impulse buying tendency and to assess whether they act as mediating variables. This research will help to people to know the behavior of Pakistani consumer related to developed countries.

\subsection{Objectives}

The principal objective of this study is to empirically examine, advance and further the present understanding related to the role of store environment, consumer personality traits stimulating impulse buying. This issue is prominent in the area of impulse buying because it will enhance the marketers' understanding of such behavior and will guide them in using store environment and consumer personality traits. Furthermore, this study also makes an attempt to examine the influence of demographic variables on impulse buying tendency and to assess whether they act as mediating variables.

\subsection{Significance}

This study carries significance both for the academia and professionals. For academia, this study is another addition to the general body of knowledge as this study is devised in such a manner that it explores the underlying dynamics of impulsive personality traits and store environment on impulse buying of consumer. This study combines the store environment and impulsive personality traits and their effect on impulse buying behavior In Pakistan's region specifically in Karachi. The study also proposes the positive impact of store environment on impulsive buying tendency that leads to urge to buy and finally impulsive purchase. The study also help marketers should identify ways to reach out open ended and extrovert people to target their promotional offers. This study will also help researchers and marketers to know the buying behavior of Pakistani people related to the people of developed countries.

\subsection{Research Questions}

The main purpose of this research study relies on some of the research question, which defined below:

Q1. Does a good store environment have a significant positive effect on impulse buying tendency or not?

Q2. Does impulsive buying personality trait, is significantly associated with impulse buying tendency or not?

Q3. Does Impulsive buying personality traits, is significantly and positively associated with impulse buying or not?

Q4. Does impulse buying tendency of shoppers significantly influence urge to buy impulsively or not?

Q5. Does impulse buying tendency of shopper is positively associated with impulsive buying or not?

Q6. Does gender of the respondents will influence impulse buying tendency or not?

Q7. Does Income of the respondents will influence impulse buying tendency or not?

Q8. Does shoppers' urge to buy impulsively have a significant positive impact on impulse buying or not?

\section{Literature Review}

\subsection{Relationship Between Variables}

Impulse buying is a concept of unplanned purchase without considering the consequences. Beatty and Ferrell (1998) reconstruct the definition of impulse buying "as an unpredicted and instantaneous purchase with no shopping objectives either to buy the specific product category or to fulfill a particular buying task." There are many factors that affect impulse buying behavior of consumer such as store environment which include lightning, cleanliness, color, music, crowd, sales persons and display. Stores with proper lighting, music, color, scent and displays will inspires the shoppers to visit the store again next time in the future (Yoo,Park, \& MacInnis, 1998).

Another factor that influences impulse buying is impulse buying tendency which means shoppers tend to buy more when they come across attractive or creative products. Most of the researchers also concluded that shoppers counting high on impulse buying tendency express more urges to buy and encourage impulsive purchase (Beatty \& Ferrell, 1998; Dawson \& Kim, 2009; Mohan, Sivakumaran, \& Sharma, 2013).

The factor which also affects impulse buying is urges to buy impulsively. It's a belonging of shoppers that they feel sudden urges to buy a specific or non-specific goods or services. According to the KPMG 2014 report approximately $50 \%$ individual related factors crate the urge to explore, which lead to impulse buying. 
Personality traits have greater impact on shopping behavior of consumers. Many researchers indicated that lack of control or loss of self-control is an important dimension of impulsiveness for monitoring impulse (Vohs \& Faber, 2007; Youn \& Faber, 2000). Consumer's lack of self-control signifies his/her inability to postpone inner satisfaction, which leads to impulse buying. The gender and monthly of the individuals have effect on impulse buying. Many research concluded that females are more prone towards impulse buying while some showed that males are more attractive towards impulse buying.

\subsection{Impulse Buying}

Known as one of the most prompting factors in retailing, impulsive buying is an unplanned, spur-of-the-moment "urge to buy" instantly (Rook, 1987; Stern, 1962).In impulse buying, individual's mainly focuses on the instant satisfaction of its emotional need "urge to buy" rather than on functional need. Rook and Gardner (1993) define impulse buying as "rapid decision-making, and a subjective partiality in favor of instant ownership." Beatty and Ferrell (1998) reformulated the impulse buying definition "as an unexpected and immediate purchase with no shopping intentions either to buy the specific product category or to fulfill a particular buying task".

According to the recent international researches it has been clearly defined that impulse buying is influenced by personal factors such as effect of money availability. Availability of money plays an important role in the process of impulse buying (Beatty \& Ferrell, 1998). A shoppers shopping design can be changed if he/she has more handsome amount. It enhances the purchasing power of shopper (Foroughi, Buang, \& Sadeghi, 2012). According to Luo (2004), there is a positive relationship between spontaneous purchase and money availability of generation Y. Nor, Ruzita, Che, and Syer (2014) specified that impulse buying behavior has positive influence with the credit card availability. Khan, Hui et al. (2015) concluded that personal factors (money and credit card available) and demographic factors (income) impacts impulse buying behavior of generation Y. Various past studies has mentioned that income has significant influence on impulsive buying behavior in Pakistan (Awan \& Abbas, 2015; Bashar, Ahmad, \& Wasi, 2012).

Other personal factors that influence impulse buying are effect of family influence and effect of time availability.

According to some previous findings, friends, family and acquaintances can impacts a person's shopping pattern. It has been observed that modern retail setting attract more friends, couples, or groups of people will show better results in terms of their performance (Underhill, 2009). According to Parboteeah (2005), shoppers purchases are on inclined pattern in the presence of peers and the same shopper shopping pattern are on declined in the presence of family members, because the family relatives are more concern about the economic issues. And that is the reason of decrease impulse buying (Luo, 2005). Surprisingly, results of some studies are inconsistent, discloses negative association between shopping with family relatives and impulse buying. Anić and Radas (2006) revealed that in the presence of companions and children, impulse buying increases as the children are more attracted towards appealing settings. In the society, individual's gives more value to their family and children as compare to their own necessities. So the impulse buying is increase when the individual purchase for their loved once.

According to different international studies, it is concluded that the more shopper spent time in the store the more chances of impulse purchase increase. As it has been figured out (Foroughi et al., 2012; Underhill, 2009), the time availability has positive impact on impulse purchase, as a shopper have more time so they stay late at the store the greater are his/her chances of impulse buying and tend to buy more as prior planning. Khan, Hui et al. (2015) mentioned that situational factors (e.g., time) impacts the impulse buying behavior of shoppers. It is reported by Nicholls (1997), that the purchase power of shoppers who are quick to buy is less as compare to the people who stays late in the store.

\subsection{Impulse Buying Tendency}

According to psychologists, each and every individual has a unique tendency to act impulsively. Several studies on consumer buying behavior illustrate that buyers differ in their impulsive shopping liking (Beatty \& Ferrell, 1998; Rook, 1987; Rook \& Fisher, 1995; Rook \& Gardner, 1993). Rook (1987) defines "consumer impulsivity as a lifestyle trait." It is useful to think of consumer impulsivity as a lifestyle trait." Most of the researchers also concluded that shoppers counting high on impulse buying tendency express more urges to buy and encourage impulsive purchase (Beatty \& Ferrell, 1998; Dawson \& Kim, 2009; Mohan, Sivakumaran, \& Sharma, 2013). On the other hand, demographic appeals of the consumer such as age, gender, income, education and marital status have impact on consumer purchase decision. Literature shows that there is a conflict of finding in the relationship between gender and impulse purchasing; few studies suggest that women are more impulsive than men (Dittmar, Beattie, \& 
Friese, 1995). A study by Cobb and Hoyer (1986) established that men show more impulsive buying tendency than women. In contrast, Verplanken and Herabadi (2001) reveal that IBT is not correlated with gender.

Rook and Fisher (1995) defined impulse buying tendency concept as a consumer trait, which demonstrate that shoppers likes to make unplanned and spontaneous decisions when they have tendency to buy. The craving of instant satisfaction (Siorowska, 2011) for the product or services is a reaction of store environment (Newman \& Patel, 2004), such as store ambiance, product displays, lightings, soft music, aromas and promotional activities lift unexpected purchase behavior, by persuading positive emotions to get profit from the product (Rook, 1987).

The studies have shown that shoppers buy low price product more impulsively as compare to the product which are highly expensive and required careful planning. In general, impulse buying tendency of shopper is natural and sign of general impulse buying tendency attribute (Jones et al., 2003).

Thus, the impulse buying tendency of shoppers shows impulse buying behavior on getting impulse. Therefore, it is significant to see the association between impulse buying tendency and impulse buying.

\subsection{Urge to Buy Impulsively and Impulse Buying}

Reliable with past studies on impulse buying, impulse purchasing has been used as an endogenous variable. Previous studies on impulsive shopping suggest that it's hard to control the urges during physical closeness of the product, while attractive display also creates urge to buy more (Dholakia, 2000; Baumeister, 2002; Beatty \& Ferrell, 1998; Mohan, Sivakumaran, \& Sharma, 2013; Rook, 1987).

According to the KPMG 2014 report approximately 50\% individual related factors crate the urge to explore, which lead to impulse buying. It includes both actual buying of product or satisfaction of the urge but there is a possibility of increasing impulse purchase if the shopper experience more urges (Beatty \& Ferrell, 1998; Mohan, Sivakumaran, \& Sharma, 2013; Weinberg \& Gottwald, 1982).

(Lee and Kacen, 2002), in urge to buy impulsively generally all information and selective options are blocked as it is defined as a series of sudden, forced and enjoyable buying that contain the decision making process of goods and services. The concept of an urge to buy impulsively is demonstrated as the purpose and the craving to obtain a product .As the product or commodities come in viewing of the shopper the shopper's desire to purchase the product spontaneously without thinking.

Urge to buy impulsively may be a way to refurbish an undesirable psychological state of affairs. Mick and Demoss, 1990 revealed that people's used to earn a prize for themselves, a possible way to make them feel better after they were disappointed or upset.

\subsection{Store Environment}

Stores with proper lighting, music, color, scent and displays will inspires the customers to visit the store again in the future (Yoo, Park, \& MacInnis, 1998). Store environment factors like lighting, aroma, Sounds/music, Presence of sales representative, crowd inside the store, store layout, color and display are dynamic component that can motivate the consumer desire to purchase impulsively (Baker et al., 2002; Mattila \& Wirtz, 2008; Rook \& Fisher, 1995).

According to Mohan, Sivakumaran, \& Sharma (2013) lighting and music have a positive impact on shoppers that simultaneously increases the chances of their impulse purchase. The Babin and Kim (2001), studies defined that the systematic and appealing arrangement of supplies in the store other than lighting and colors dominantly affects the shopping behavior of the shoppers. Akram, Hui, Khan, Hashim, and Rasheed (2016) investigated the impact of store environment on impulse buying behavior, and concluded the result that reveals that store environment has dominant and positive effect on impulse buying behavior.

If the shopper is satisfied with the store environment it impacts on his/her emotion and have chances of impulse purchase or they do more shopping from the store. On the other hand, there are many studies concluded that store atmosphere has no significant effect on purchasing behavior and it never change the decision pattern of their shopping (Nicholls 1997).

There are many international studies concluded sales promotion and informative salesperson has greater positive impact on impulse buying of shopper. According to many research the discount and promotion has influence on impulse purchase of shopper (Abratt \& Goodey, 1990; Stern, 1962). Jamal and Lodhi (2015) revealed that there is an association between shopper's impulse buying behavior and promotional activities so the sales and promotional activities has directly proportional to the shopper impulse buying behavior. It is defined that friendly salesperson with adequate information about the product, admires shoppers, solves their queries, then they give stimuli the process of impulse buying (Virvilaite et al., 2009; Yu \& Bastin, 2010). 
Some researcher suggests that the employee friendliness should be considered as an important factor in the retail store environment (Saad \& Metawie, 2015). Responsive employees are vital to fulfill shopper's needs and wants; the shoppers feels good and purchases more if the employees help in their decision making and the selection of product by providing them adequate information about the product or commodities.

\subsubsection{Cleanliness}

Cleanliness of the stores creates greater impact of relaxation and comfort in the shopper's mind due to which shoppers spend more time in the retail chain outlets and make more purchases (Yun\& Good, 2007).

\subsubsection{Music}

Many studies revealed that music played in retail chain outlet is significantly influence consumer purchase intention. Music styles and beats intensely affect shoppers in increasing sales of the retail outlets. The longer consumption time is influenced by pleasant music (Holbrook \& Anand, 1990). Music has a helpful impression on the shoppers' sum of time and money spent due to good store environment (Herrington, 1996).

\subsubsection{Scent}

The retail chain outlet that contains good music and scent stimulates shoppers to spend more time in the shopping (Yalch, Richard, Eric, \& Spangenberg, 2000). Choice of one odor should be preferable over multiple odors. Many studies have suggested that shoppers spend more cash at the retail chain outlets with single odor in comparison to those shoppers who come across to multiple fragrances (Haberland, 2010).

\subsubsection{Temperature}

Temperature at retail chain outlet is among those atmospheric variables that greatly affects the shopper purchase intention. Extreme temperature-very low or very high-creates negative feelings among shoppers; it leads to disappointment among the shoppers and consequently, shoppers produce negative word of mouth and spend less time in the retail chain outlet while shopping (Lam, 2001).

\subsubsection{Lighting}

Lighting is used to highlight or make products more visible. It creates excitement and has a positive impression on consumer purchasing behavior (Mehrabian \& Albert, 1976). When the lighting used in the retail chain outlets is of good color, shoppers are motivated to touch products to assess quality (Areni \& Kim, 1994). The main purpose of using brighter lighting in retail outlets is to grab the shopper's attention so that they start purchasing from the outlets due to their comfort.

\subsubsection{Color}

Color has positive impact on the consumer's perception about the commodities (Yuksel, 2009). The good and soft color of retail chain outlets helps in creating attention and positive perception about the commodities available in the outlet (Crowley, 1993).

\subsubsection{Display / Layout}

Design and display of products in the retail chain outlets contribute one fourth sales of the outlets (Mills, Paul, \& Moorman, 1995). The systematic arrangement of the product display has strong association between shoppers purchase intention and shoppers perception about the product. The display of the products in the stores influenced shopper movement in the stores massively (Ward, Bitner, \& Barnes, 1992).

\subsection{Store Environment and Impulse Buying Tendency}

Numerous researches have examined the effects of display and have identified that attention-grabbing display/demonstration can pointedly influence sales. Hulte'n and Vanyushyn (2011) discovered that attractive and eye-catching displays have direct influence on buyer impulsive behavior. The influence of retailing and exclusive displays on impulsive shopping behavior is universal phenomenon (Beatty \& Ferrell, 1998; Dholakia, 2000; Hulte'n \& Vanyushyn, 2011; Mattila \& Wirtz, 2008; Wu, Chen, \& Chien, 2013; Xiao \& Nicholson, 2011).

Sound or background music plays an important role in retail chain environment that impacts the purchasers' desire to connect in buyer-seller interactions. Other store environmental attributes like smell/ aroma have also been supposed to effect purchasing performance (Beverland et al., 2006; Chebat, Chebat, \& Vaillant, 2001). All these signs of the store create an impactful positive relationship with impulse buying (Park \& Lennon, 2006).

Chang, Eckman, and Yan (2011) indicated that atmosphere of the store creates a caring emotion among the shoppers. This caring emotion will surely uplifts shopper's pleasure, moods and fulfill shoppers desire, which ultimately 
impacts their impulse buying tendency. Babin and Attaway (2000) have also submitted that the positive effect of store environment on the shopper mind that helps in minimizing negative word of mouth.

According to Spies, Hesse, and Loesch, (1997), retail layouts spread shoppers' experience by helping them to quickly find what they desire. The good layout creates shopping more enjoyable and stress free (Baker et al., 2002). Various studies have also deliberated that the impact of social communication between buyers and sales personnel constructs impulse purchasing.

As per Stern (1962), such sales personnel facilitate the formation of urge among the prospective buyers. Store sales personnel impacts store experience of shoppers (Jones, 1999). Often, subtle aspects in the employee's behavior can be associated with positive feeling for shoppers, for example being easily available for shoppers, give appropriate information about the product or just a simple smile can greatly boost shopper experience.

\subsection{Impulsive Personality Traits}

The word "personality" has been derived from the Latin term persona, which means to cover. Bozionelos (2004) analyze that personality is comprised of intellectual, rational, behavioral and social patterns. Schiffman and Kanuk (2008) describe personality as a unique, typical and vibrant group which is composed of several physical and psychological characteristics of an individual, having a direct impact on the attitudes, actions, and reactions to the social and physical surroundings. Larsen, Cervone and Butterworth (2010) describe the personality of an individual as a package containing mental, emotional features and mechanism in a systematized pattern and are comparatively long term.

Impulsivity is demonstrated as an aspect of the personality which enables a shopper to make rapid movements without deep thinking or considering alternative better choice (Roberts, Pullig, \& Manolis, 2015). The impulsive personality trait is different from one individual to another individual (Andreassen et al., 2013). Impulsive shopping is also a lack of self-control of an individual which is ultimately related to the personality. The affinity to indulge into impulsive buying is because of sudden and instantaneous desire to buy the product (Liu, $\mathrm{Li}, \& \mathrm{Hu}, 2013$ ).

Past studies indicate that impulsive buying behavior is a buyer personality trait (Beatty \& Ferrell, 1998; Verplanken \& Herabadi, 2001). Clinical and developmental psychologists, education researchers, and criminologists have studied the general trait of impulsiveness and it has been considered as a basic human trait. Impulse buying may be a demonstration of "personality trait" associated with "lack of control". Many researchers indicated that lack of control or loss of self-control is an important dimension of impulsiveness for monitoring impulse (Vohs \& Faber, 2007; Youn \& Faber, 2000).

Consumer's lack of self-control signifies his/her inability to postpone satisfaction, which leads to impulse buying. According to Rook and Fisher (1995), "impulsive buyers are more likely to experience spontaneous buying stimuli; their shopping lists are more open and receptive to sudden, unexpected buying ideas." Verplanken and Herabadi (2001) exhibited that cognitive aspects of shoppers were associated with low need to evaluate, and a lack of conscientiousness. The sudden and immediate or lack of planning while, purchasing products are few of the characteristics of impulse buyers influencing their impulse buying tendency.

According to recent international research OCEAN model of personality which stands for Openness, Conscientiousness, Extraversion, Agreeableness and Neuroticism, which almost cover the entire human personality attributes (Andreassen et al., 2013; Roberts et al., 2015). The big five model or OCEAN model helps an individual to study the basic and essential set of behavioral characters (Feldman, 2010; Larsen, Cervone, \& Butterworth, 2010).

Mondak (2010) expresses openness as a characteristic in which a peer tends to have stretchy behavior and neither is rigid for themselves nor for others. Hogan, Barrett and Hogan (2007) associate openness to the individual's creativity. On the other hand, openness can also be described as the opposite of conservative and close-mindedness (John \& Srivastava, 1999). People who are open-minded learn things very quickly and have adventurous and diversified nature (John, Naumann, \& Soto, 2008). Peoples who are in declining score in this trait are quite conservative, having limited mental and behavioral level, they are also quite reserved and even do not share their emotion too while on the contrast, individuals who are on incline position in this traits are entertaining, adventurous, ready to do new things and even come up with new ideas (Hirsh, 2010). It is anticipated that open minded people have a tendency to accept or try out new products.

Conscientiousness is a personality trait which expresses the socially prescribed impulse control that permits task and goal oriented behavior of an individual. It is a personality trait which replicates how one individual differs from another in terms of their self-control, responsibilities, reliability and hard work (McCrae \& Costa, 2008; Roberts, Lejuez, Krueger, Richards, \& Hill, 2014). The individuals scoring high in this trait emphasis more on their future 
forecasting and expenses, which ultimately restricts them to go for impulse buying (Leong, Jaafar, \& Sulaiman, 2017; Donnelly, Iyer, \& Howell, 2012; Verplanken \& Herabadi, 2001).

Extraversion trait mainly deals with the tendency of socializing, confidence, assertiveness, anticipation and enjoyment (Mooradian \& Swan, 2006). Extravert people are talkative and become more energetic when interacting with other individuals (John et.al, 2008). Individuals, scoring low on this trait, are not so friendly. They make their own empire, love to be dependent and don't prefer to rely on others. People who have high score on this trait are always positive minded, confident, constructive (Watson \& Clark, 1991), energetic, enthusiastic, and quite active who love to socialize (John \& Srivastava, 1999).

According to McCrae and Costa (2008), agreeableness deals with the intentions that drive people to maintain and uphold positive relationships with other people. Individuals falling high in this trait are noble, self-sacrificing, philanthropic, concerned, understanding and compassionate. Individuals with the high score on this trait tend to be sensible and think before act. It is anticipated that they are less likely to go for impulse purchase (Verplanken \& Herabadi, 2001).

Neuroticism is related with the normal personality, which facilitates the affinity of an individual to experience harsh and damaging effects of anxiety, distress, grief, unhappiness, humiliation, embarrassment, antagonism, guiltiness and antipathy. Individuals scoring high score in this trait might be facing some psychiatric issues, and are not emotionally stable and could have negative emotions, individual with this personality traits are short tempered and moody and even sometime come up with irrational, illogical and unreasonable ideas that eventually end up with negative outcomes (John et.al, 2008). According to Hough, Eaton, Dunnette, Kamp and McCloy (1990), low score in this trait indicates emotional stability, Such individuals face their challenges and problems strongly. There is a progressive relation between neuroticism and impulse buying behavior because the anxiety or the emotional distress leads people to make an impulse purchase after which they feel bit relieved and relaxed (Shahjehan, Jaweria, Qureshi, Zeb, \& Saifullah, 2012; Silvera, Lavack, \& Kropp, 2008).

\subsection{Conceptual Framework}

Sound or background music plays an important role in retail chain environment that impacts the purchasers' desire to connect in buyer-seller interactions. Other store environmental attributes like smell/ aroma have also been supposed to effect purchasing performance (Beverland et al., 2006; Chebat, Chebat, \& Vaillant, 2001). All these signs of the store create an impactful positive relationship with impulse buying. Thus it is hypothesized as

'A good store environment has a significant positive effect on impulse buying tendency.'

Verplanken and Herabadi (2001) exhibited that cognitive aspects of shoppers were associated with low need to evaluate, and a lack of conscientiousness. The sudden and immediate or lack of planning while, purchasing products are few of the characteristics of impulse buyers influencing their impulse buying tendency. Thus the hypotheses are generated;

'Impulsive buying personality traits, is significantly associated with IBT.'

'Impulsive buying personality traits, is significantly and positively associated with impulse buying.'

Most of the researchers also concluded that shoppers counting high on impulse buying tendency express more urges to buy and encourage impulsive purchase (Beatty \& Ferrell, 1998; Dawson \& Kim, 2009; Mohan, Sivakumaran, \& Sharma, 2013). It is also concluded that impulse buying tendency creates impulse buying. There is a conflict of finding in the relationship between gender and impulse purchasing; few studies suggest that women are more impulsive than men (Dittmar, Beattie, \& Friese, 1995). A study by Cobb and Hoyer (1986) established that men show more impulsive buying tendency than women. In contrast, Verplanken and Herabadi (2001) reveal that IBT is not correlated with gender. On the basis of discussion following hypothesis constructed.

'IBT of shoppers significantly influences urge to buy impulsively.'

'IBT of shopper is positively associated with impulsive purchasing.'

'Gender of the respondents will influence IBT.'

'Income of the respondents will influence IBT.'

Previous studies on impulsive shopping suggest that it's hard to control the urges during physical closeness of the product, while attractive display also creates urge to buy more (Dholakia, 2000; Baumeister, 2002; Beatty \& Ferrell, 1998; Mohan, Sivakumaran, \& Sharma, 2013; Rook, 1987).

'Shoppers' urge to buy impulsively has a significant positive impact on impulse buying.' 


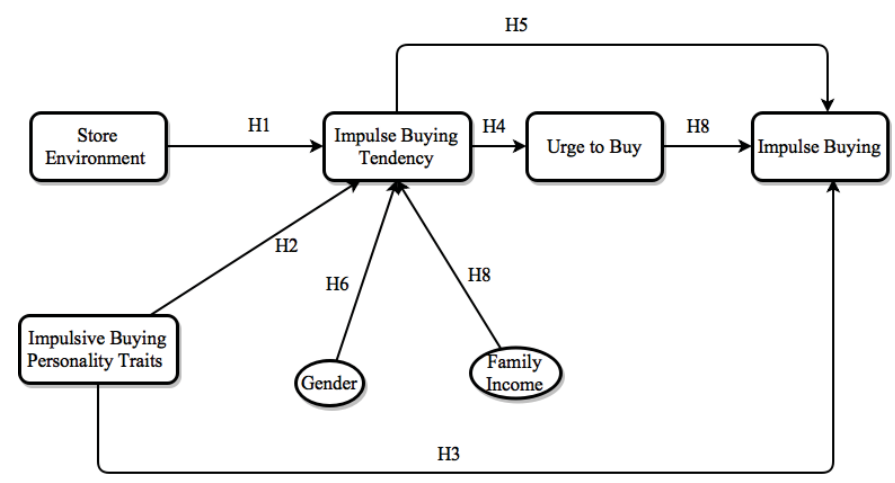

Proposed hypothesized model

\subsection{Hypothesis Development}

Following hypotheses have been devised for this study keeping in view the literature;

\begin{tabular}{ll}
\hline H1 & A good store environment has a significant positive effect on IBT. \\
\hline H2 & Impulsive buying personality traits, is significantly associated with IBT. \\
\hline H3 & Impulsive buying personality traits, is significantly and positively associated with impulse buying. \\
\hline H4 & IBT of shoppers significantly influences urge to buy impulsively. \\
\hline H5 & IBT of shopper is positively associated with impulsive purchasing. \\
\hline H6 & Gender of the respondents will influence IBT. \\
\hline H7 & Income of the respondents will influence IBT \\
\hline H8 & Shoppers' urge to buy impulsively has a significant positive impact on impulse buying. \\
\hline
\end{tabular}

\section{Research Methodology}

\subsection{Introduction}

This chapter sheds light on the methods and techniques adopted to address the research questions. The design and overall strategy has been discussed. The method of the data has been discussed with detail. The sample size has been accounted in detail. The statistical tests have been discussed too.

\subsection{Research Design}

This study uses a quantitative research design using questionnaire, in which, the data has been analyzed using quantitative techniques.

\subsection{Sampling}

The aim of the research was to examine the influence of impulsive personality traits and store environment on impulse buying of consumer in Pakistan's region. For this purpose, a quantitative approach was adopted, using different questionnaires submitted to respondents face-to-face and also by online means.

The sample size was 250 respondents. The author's has collected the data by personally distributing the questionnaire at different supermarkets business collage and universities specifically in Karachi and also by online means irrespective of any credentials. A five-point Liker scale was used to caliber the responses, where ' 1 ' and ' 5 ' signified "Strongly disagree" to "Strongly agree" respectively

The survey instrument comprises of statements that addressed retail store environmental features, IBT, urge to buy and impulsive buying personality traits. To examine buyers' perceptions of store environmental features, Mohan, Sivakumaran, and Sharma (2013) scale was modified to include music, light, layout and sales person. Other variables of store environment factor were adopted from different studies - colour (Chebat, Chebat, \& Vaillant, 2001), crowd (Mattila \& Wirtz, 2008). Beatty and Ferrell (1998) scale consisting of three items were used to measure consumers' 
urge to buy. To examine the impulsive buying personality traits, the scale developed by Rook and Fisher (1995) was used.

\subsection{Statistical Techniques}

The collected data was analyzed applying a two-stage structural equation modeling approach as recommended by Anderson and Gerbing (1988). The measurement model was analyzed with the help of confirmatory factor analysis, followed by testing the structural model using path analysis.

\section{Results and Findings}

\subsection{Frequency Analysis}

The descriptive analysis run via SPSS shows that out of total 250 sample size, male's accounts for $48 \%$ of total sample and female accounts for $52 \%$ as shown in following table; More than $80 \%$ of the sample lied between 18 and 29 years. More than $61 \%$ of respondents had a monthly income lied between 30000-45000, whereas $68 \%$ respondents were single. Approx. $62 \%$ respondents were employed in different organization and more than $84 \%$ are university graduate or continuing their studies.

Table 1. Demographic profile of the population and samples

\begin{tabular}{|c|c|c|}
\hline Variable & Frequency & Population (\%) \\
\hline \multicolumn{3}{|l|}{ Gender } \\
\hline Male & 119 & 47.6 \\
\hline Female & 131 & 52.4 \\
\hline \multicolumn{3}{|c|}{ Age of Respondent } \\
\hline $18-29$ & 205 & 82.0 \\
\hline $30-49$ & 39 & 15.6 \\
\hline $50-55$ & 4 & 1.6 \\
\hline Above 55 & 2 & 0.8 \\
\hline \multicolumn{3}{|c|}{ Level of Education } \\
\hline Primary & 0 & 0 \\
\hline Secondary & 1 & 0.4 \\
\hline College & 37 & 14.8 \\
\hline University & 212 & 84.8 \\
\hline \multicolumn{3}{|l|}{ Job Status } \\
\hline Student & 77 & 30.8 \\
\hline Housewife & 17 & 6.8 \\
\hline Employed & 156 & 62.4 \\
\hline Retired & 0 & 0 \\
\hline \multicolumn{3}{|l|}{ Marital Status } \\
\hline Single & 170 & 68.0 \\
\hline Married & 75 & 30.0 \\
\hline Divorced & 2 & .8 \\
\hline Others & 3 & 1.2 \\
\hline \multicolumn{3}{|l|}{ Income } \\
\hline $18,000-25,000$ & 49 & 19.6 \\
\hline $30,000-45,000$ & 64 & 25.6 \\
\hline $50,000-75,000$ & 71 & 28.4 \\
\hline $80,000-100000$ & 66 & 26.4 \\
\hline
\end{tabular}




\subsection{Descriptive Analysis}

Initially, all the 30 items containing the store environment, impulse buying tendency, urges, impulse buying and impulsive personality traits scale had their variability measured. The 30 items showed acceptable means and standard deviations specified the scale range from 1 to 5 (the individual item means ranged from '2.1' to '4.1'; while standard deviations ranged from ' 0.93 ' to '2.1'). As from above analysis it can be observed that the mean values which are above 3 that's describes the respondents are agreeing on those question regarding store-environment, impulse buying tendency, urge to buy, and impulsively personality traits. But the questions whose value is less than 3 describes, respondents are not agreeing on those statements.

Table 2. Descriptive statistics

\begin{tabular}{|c|c|c|c|}
\hline Variable description & Mean & & Std. Deviation \\
\hline & Statistic & Std. Error & Statistic \\
\hline $\begin{array}{l}\text { The lightning in the outlets is pleasing to the eyes, and makes me to } \\
\text { stay more. }\end{array}$ & 3.69 & .059 & .939 \\
\hline $\begin{array}{l}\text { The lightning of the outlets makes things more visible and attractive } \\
\text { to me. }\end{array}$ & 3.84 & .047 & .749 \\
\hline Listening to music creates a relaxed atmosphere while shopping. & 3.49 & .061 & .962 \\
\hline Music in store motivates me to buy more. & 2.31 & .049 & .769 \\
\hline The cleanliness of the outlet floor motivates me to buy more. & 2.34 & .075 & 1.178 \\
\hline The cleanliness of retail chain outlet attracts me to visit again. & 3.78 & .064 & 1.019 \\
\hline Scent in retail chain outlet encourages me to purchase more. & 2.46 & .073 & 1.158 \\
\hline $\begin{array}{l}\text { Retail chain outlets with air-conditioning courage me towards } \\
\text { shopping. }\end{array}$ & 4.10 & .053 & .845 \\
\hline The color of retail outlet makes positive perception in my mind. & 3.76 & .048 & .766 \\
\hline $\begin{array}{l}\text { I tend to buy more when I come across attractive and impressive } \\
\text { displays. }\end{array}$ & 3.21 & .065 & 1.032 \\
\hline $\begin{array}{l}\text { The creative and systematic arrangement of products in the retail } \\
\text { chain outlet helps me in the selection of product. }\end{array}$ & 3.97 & .066 & 1.043 \\
\hline $\begin{array}{l}\text { Informative employees influence my buying decision for impulse } \\
\text { buying. }\end{array}$ & 3.31 & .070 & 1.101 \\
\hline Crowd in the store stimulates me to purchase. & 1.91 & .065 & 1.026 \\
\hline I had not intended to buy. & 2.93 & .049 & .776 \\
\hline I am a person who makes unplanned purchases. & 2.67 & .085 & 1.346 \\
\hline I buy it without considering the consequences. & 2.56 & .060 & .948 \\
\hline Fun to buy spontaneously. & 2.82 & .068 & 1.072 \\
\hline Sudden urges to buy. & 2.72 & .062 & .983 \\
\hline Tempted to buy many items. & 2.65 & .062 & .976 \\
\hline I experience no sudden urge to buy. & 2.61 & .070 & 1.101 \\
\hline Buying more than I had planned to buy. & 2.95 & .076 & 1.198 \\
\hline
\end{tabular}




\begin{tabular}{llll}
\hline I spend more money than I had planned to buy. & 2.91 & .084 & 1.322 \\
\hline Buy things spontaneously. & 2.94 & .061 & .967 \\
\hline Buy things according to how I feel at that moment. & 3.83 & .133 & 2.100 \\
\hline Carefully plan most of my purchases. & 3.24 & .094 & 1.492 \\
\hline "I see it, I buy it". & 2.74 & .061 & .969 \\
\hline I am a bit reckless about what I buy. & 2.62 & .063 & 1.000 \\
\hline I often buy things without thinking. & 2.66 & .068 & 1.068 \\
\hline I feel like buying things on the spur-of-the moment. & 2.70 & .064 & 1.008 \\
\hline "Buy now, think about it later. & 2.13 & .074 & 1.170 \\
\hline Valid N (listwise) & & & \\
\hline
\end{tabular}

\subsection{Infrential Statistics}

To measure the impact of impulsive personality traits and store environment on impulse buying of consumer in Karachi for which different test were applied to check the reliability and effect of each factor. Cronbach's Alpha is test used to check the reliability. Inferential statistics helps to make inferences and conclusive evidence from the sample data drawn from a population (Gillet, Fouquereau, Forest, Brunault, \& Colombat, 2012; Inoune, Kawakami, Tsuno, tomioka \& Nakanishi, 2012; Rita Silva \& Caetano, 2014.

\subsubsection{Relaibility}

Reliability test was done to assess the significance of data (J. Nunnally, 1978; J. C. Nunnally \& Bernstein, 1994). In above table the values of reliability test show acceptable results with all items included and individually of each variable. The reliability of all the variables including dependent and independent variables is greater than the cut off value that is 0.70 which was good (Santos, 1999). Cronbach's alpha is a measure used to assess the reliability, or internal consistency, of a set of scale or test items. In other words, the reliability of any given measurement refers to the extent to which it is a consistent measure of a concept, and Cronbach's alpha is one way of measuring the strength of that consistency.

The alpha coefficient for store environment is 0.700 , suggesting that the items lie in the acceptable range and have higher internal consistency. (Note that the value of coefficient is .70 or higher is considered "acceptable", or less than .07 is moderate, Coefficients that are less than 0.5 are usually unacceptable), in a same way impulse buying tendency has 0.804 (which is also acceptable), urges has 0.667 (which is also acceptable), impulse buying 0.884 and impulsive personality has alpha value 0.725 which is also acceptable.

Table 3. Reliability statistics for each variable

\begin{tabular}{ll}
\hline & Cronbach alpha \\
\hline Store environment & 0.700 \\
\hline Impulse buying tendency & 0.804 \\
\hline Urges & 0.667 \\
\hline Impulse buying & 0.884 \\
\hline Impulsive personality traits & 0.725 \\
\hline
\end{tabular}

Overall Cronbach's Alpha of the questionnaire was 0.851. Which is significant as it is greater than the cut off value which is 0.7 . Besides buying behavior indicates 0.8 reliability which is also acceptable as it falls between the standard ranges of 0.5-0.9. This depicts appropriate grounds to assert that internal consistencies in the data are quite significant and thus, the answers of the respondents display that the results would be reliable. 
Table 4. Reliability statistics

\begin{tabular}{lll}
\hline Reliability Statistics & & \\
\hline Cronbach's Alpha & Cronbach's Alpha Based on Standardized Items & N of Items \\
\hline .851 & .858 & 36 \\
\hline
\end{tabular}

\subsubsection{Confirmatory Factor Analysis Using AMOS}

Confirmatory factor analysis was performed using AMOS. Factor analysis was employed to reduce large number of variables to extract most underlying variables called factor. Confirmatory factor analysis is a useful method to examine the variability among observed variables and excerpt variability from items and load them into a common factor. As the study entails exploratory nature, factor analysis was done to identify the most important construct, i.e. Store environment, impulse buying tendency, Urge to buy impulsively and impulsive personality traits.

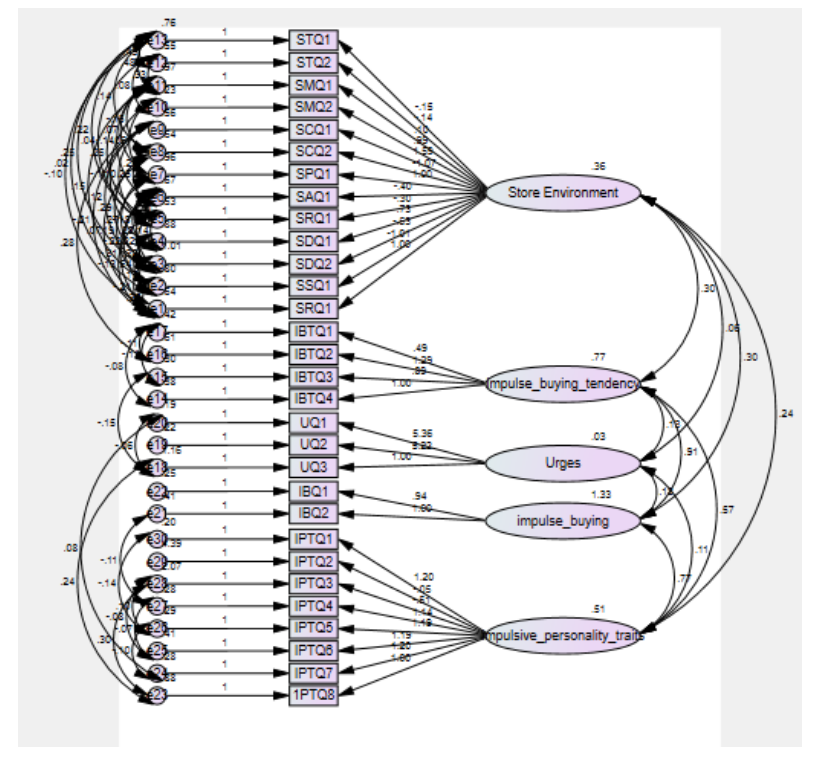

Figure 1. Confirmatory Factor Analysis Using AMOS - CFA Model

The table shows Standardized factor loading for each item and shows the association between individual items with the extract construct. Factor loading for each item depicts reasonable to strong relationship with the underlying construct.

Table 5. Standardized regression weights

\begin{tabular}{|c|c|c|c|}
\hline $\begin{array}{l}\text { Latent } \\
\text { Variable }\end{array}$ & Item Label & Item Description & $\begin{array}{l}\text { Standardized } \\
\text { Factor } \\
\text { Loading }\end{array}$ \\
\hline \multirow[t]{5}{*}{$\begin{array}{l}\text { Store } \\
\text { Environment }\end{array}$} & STQ1 & $\begin{array}{l}\text { The lightning in the outlets is pleasing to the eyes, and makes } \\
\text { me to stay more. }\end{array}$ & -.102 \\
\hline & STQ2 & $\begin{array}{l}\text { The lightning of the outlets makes things more visible and } \\
\text { attractive to me. }\end{array}$ & -.111 \\
\hline & SMQ1 & Listening to music creates a relaxed atmosphere while shopping. & .039 \\
\hline & SMQ2 & Music in store motivates me to buy more. & .757 \\
\hline & SCQ1 & The cleanliness of the outlet floor motivates me to buy more. & .793 \\
\hline
\end{tabular}




\begin{tabular}{|c|c|c|c|}
\hline & SCQ2 & The cleanliness of retail chain outlet attracts $m$ to visit again. & -.617 \\
\hline & SPQ1 & Scent in retail chain outlet encourages me to purchase more. & .512 \\
\hline & SAQ1 & $\begin{array}{l}\text { Retail chain outlets with air-conditioning courage me towards } \\
\text { shopping. }\end{array}$ & -.287 \\
\hline & SRQ1 & The color of retail outlet makes positive perception in my mind. & -.224 \\
\hline & SDQ1 & $\begin{array}{l}\text { I tend to buy more when I come across attractive and impressive } \\
\text { displays. }\end{array}$ & .411 \\
\hline & SDQ2 & $\begin{array}{l}\text { The creative and systematic arrangement of products in the } \\
\text { retail chain outlet helps me in the selection of product. }\end{array}$ & -.266 \\
\hline & SSQ1 & $\begin{array}{l}\text { Informative employees influence my buying decision for } \\
\text { impulse buying. }\end{array}$ & -.570 \\
\hline & SRQ1 & Crowd in the store stimulates me to purchase. & .626 \\
\hline Impulse & IBTQ1 & I had not intended to buy. & .551 \\
\hline Buying & IBTQ2 & I am a person who makes unplanned purchases. & .824 \\
\hline & IBTQ3 & I buy it without considering the consequences. & .819 \\
\hline & IBTQ4 & Fun to buy spontaneously. & .819 \\
\hline Urges & UQ1 & Sudden urges to buy. & .893 \\
\hline & UQ2 & Tempted to buy many items. & .879 \\
\hline & UQ3 & I experience no sudden urge to buy. & .153 \\
\hline Impulse & IBQ1 & Buying more than I had planned to buy. & .874 \\
\hline Buying & IBQ2 & I spend more money than I had planned to buy. & .909 \\
\hline Personality & IPTQ1 & Buy things spontaneously. & .888 \\
\hline & IPTQ2 & Buy things according to how I feel at that moment. & -.012 \\
\hline & IPTQ3 & Carefully plan most of my purchases. & -.241 \\
\hline & IPTQ4 & "I see it, I buy it". & .835 \\
\hline & IPTQ5 & I am a bit reckless about what I buy. & .845 \\
\hline & IPTQ6 & I often buy things without thinking. & .799 \\
\hline & IPTQ7 & I feel like buying things on the spur-of-the moment. & .848 \\
\hline & IPTQ8 & "Buy now, think about it later. & .606 \\
\hline
\end{tabular}

\subsubsection{Evaluating Measurement Model Fitness}

To evaluate the fitness of the proposed model, Amos delivers a set of useful indices that are used to determine the fitness and validity of the hypothesized model. Out of different significant indices, root mean square error of approximation (RMSEA), goodness of fit index (GFI), Chi-Square, CMIN/DF, adjusted goodness of fit index (AGFI), and comparative fit indices were observed to determine the authenticity of the research model. The discussed indices shows the degree to which constructs are related to one another.

Table 6. Model fitness test

\begin{tabular}{lll}
\hline Model Fit & Resultant Value & Threshold \\
\hline CMIN/DF & 4.778 & $<3$ good $;<5$ Acceptable \\
\hline CFI & .779 & Closer to $1 ;$ good \\
\hline GFI & .738 & $>0.90$ \\
\hline
\end{tabular}




\begin{tabular}{lcc}
\hline NFI & .740 & $>0.90$ \\
\hline IFI & .783 & $>0.90$ \\
\hline TLI & .717 & $>0.90$ \\
\hline AGFI & .641 & $>0.90$ \\
\hline RMR & .148 & $<0.08$ \\
\hline RMSEA & .123 & $<0.08$ \\
\hline PCLOSE & .000 & $<0.05$ \\
\hline P-VALUE & .000 & 0.00
\end{tabular}

The measured values of CMIN/DF, is acceptable while PCLOSE and P-value are good and meet the threshold. However the values of AGFI, CFI, GFI, NFI, TLI, RMR and RMSEA are differs from standard values while the p-values make this model at least appropriate for research inferences.

\subsubsection{Structural Equation Model}

Structural equation modeling used to evaluate the structural relationship between exogenous and endogenous variables. The structural equation modeling includes factor analysis and multivariate analysis of the model. Firstly we evaluate the model fitness and measure whether the paths showing the relationship between measured and latent variables are significant or not. The path diagram showed in Figure 2. In this diagram store environment and impulsive personality traits towards impulse buying. Besides Table 8 shows the model fit results by analyzing model fit indices.

\subsubsection{Evaluating Measurement Model Fitness}

After analyzing the reliability and validity of the model, goodness-of-fit statistics were checked for the proposed model to examine the fit of the model with the data. The ratio of chi square minimum to degree of freedom (CMIN/DF) was 2.12, which is lower than cut-off criterion of 3.00 (Hair et al. 2006), indicating a good fit between the postulated model and the data. Hair et al. (2006) suggested that other indices like goodness-of-fit index (GFI), comparative fit index (CFI), incremental fit index (IFI) and Tucker-Lewis index (TLI) value should be greater than 0.9 . From the study, the following values were obtained for various fit indices: GFI $(=0.830)$, IFI $(=0.932)$, CFI $(=$ $0.941)$, Normed Fit Index $(\mathrm{NFI})(=0.892)$ and TLI $(=0.948)$. Root mean square error of approximation (RMSEA) was found to be $0.085,0.1$ (Hair et al. 2006). The path diagram formulated in the AMOS software is shown below.

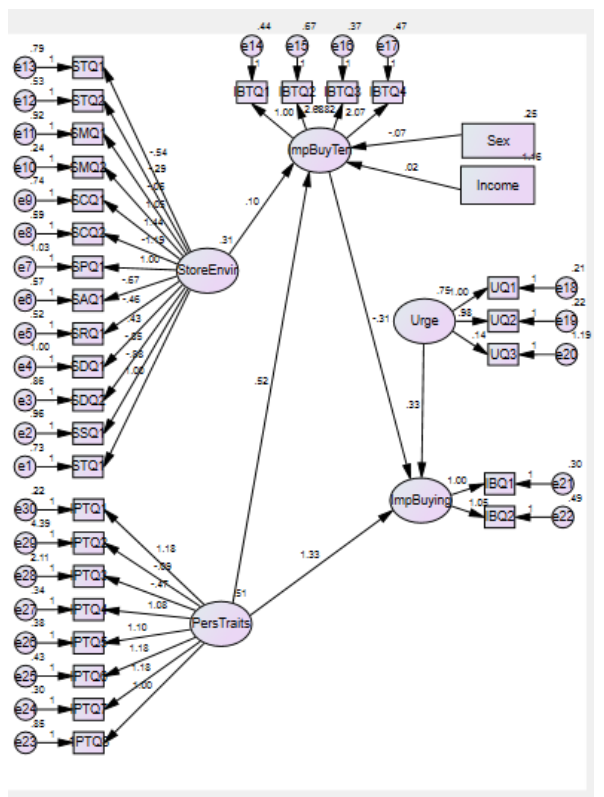

Figure 2. Path diagram 
With regard to Model fit, following table shows relevant statistics as generated by output results of AMOS.

Table 7. Model fitness test

\begin{tabular}{lll}
\hline Model Fit & Resultant Value & Threshold \\
\hline CMIN/DF & 4.193 & $<3$ good ; 5 Acceptable \\
\hline CFI & .823 & Closer to 1; good \\
\hline GFI & .763 & $>0.90$ \\
\hline NFI & .785 & $>0.90$ \\
\hline IFI & .827 & $>0.90$ \\
\hline TLI & .740 & $>0.90$ \\
\hline AGFI & .629 & $>0.90$ \\
\hline RMR & .242 & $<0.08$ \\
\hline RMSEA & .113 & $<0.08$ \\
\hline PCLOSE & .000 & $<0.05$ \\
\hline P-VALUE & .000 & 0.00 \\
\hline
\end{tabular}

There are different parameters to evaluate the goodness of a fit model. The study has adopted several model fit indices to predict model fitness. Store-environment, impulse buying tendency, Urge to buy and impulsively personality traits. As the $\mathrm{p}$ value is 0.000 which is less than 0.05 , thus model is fit for estimation. CMIN/DF value is below 5 which is also acceptable. However, for absolute fit, GFI should be greater than 0.9 and RMSEA would have value that falls within the range of $0.05 \mathrm{o} 0.08$. As, in this model, these requirements are not fulfilled; thus, this model is not absolute fit. But CFI, GFI values lies above 0.7 level it's also acceptable in some cases of model fit. Overall, model seems to be not too good fit. However, the p value of 0.000 makes this model at least appropriate for research inferences. This is also due to the fact that in SEM, estimates do not hold valid in case of unidentified model; however, our model is over-identified as shown above; Since, the degree of freedom is positive, such model is over-identified and minimum expectations for the research are met.

Table 8. Regression weights (hypothesis testing)

\begin{tabular}{|c|c|c|c|}
\hline & ESTIMATES & C.R. & $\mathrm{P}$ \\
\hline ImpBuyTen $\leftarrow$ StoreEnvir & .030 & 1.951 & .051 \\
\hline ImpBuyTen $\leftarrow$ PersTraits & .428 & 5.692 & $* * *$ \\
\hline ImpBuyTen $\leftarrow$ Gender & -.053 & -2.295 & .022 \\
\hline ImpBuyTen $\leftarrow$ Income & -.002 & -.180 & .857 \\
\hline ImpBuyTen $\leftarrow$ Urge & .155 & 5.314 & $* * *$ \\
\hline ImpBuying $\leftarrow$ Urge & .245 & 1.929 & .054 \\
\hline ImpBuying $\leftarrow$ ImpBuyTen & 1.451 & 1.792 & .073 \\
\hline ImpBuying $\leftarrow$ PersTraits & .716 & 2.071 & .038 \\
\hline
\end{tabular}

The above table shows that $\mathrm{p}$ value for store environment is 0.051 which is not less than 0.05 , thus, store environment has insignificant impact on impulse buying tendency. For the path "impulsive personality traits", $p$ value is 0.001 which shows significant relationship between impulsive personality traits and impulse buying tendency. For the gender, $\mathrm{p}$ value is .022 which is less than 0.05 but the beta-coefficient is negative so reject the influence of gender on impulse buying tendency and thus showing insignificant relationship. However, the p value 
for income and impulse buying tendency is .857 which is more than 0.05 , thus, this indicates insignificant relationship. The relationship between urge and impulse buying tendency is too significant as p value is 0.000 which is too less than 0.05 . Whereas, urge and impulse buying shows insignificant relationship as p value exceeds 0.05 . However impulse buying tendency and impulse buying also show insignificant relationship as p value is 0.073 , while impulsive personality trait and impulse buying shows significant relationship with $\mathrm{p}$ value .038 . The estimates show that impulsive personality trait and urge to buy are positively correlated with the impulse buying and impulse buying tendency. The above mentioned analyses are subjected to one assumption, which is that items used measure the constructs adequately. This assumption can be tested using a technique called from CFA, it has been confirmed that results of SEM holds valid.

\subsection{Hypothesis Assesment Summary}

\begin{tabular}{llllll}
\hline S.NO & HYPOTHESIS & P-VALUE & NATURE & RESULT \\
\hline H1 & $\begin{array}{l}\text { A good store environment has a significant } \\
\text { positive effect on IBT. }\end{array}$ & Positive & Rejected \\
\hline H2 & $\begin{array}{l}\text { Impulsive buying personality traits, is } \\
\text { significantly associated with IBT. }\end{array}$ & Positive & Accepted \\
\hline H3 & $\begin{array}{l}\text { Impulsive buying personality traits, is } \\
\text { significantly and positively associated with } \\
\text { impulse buying. }\end{array}$ & Positive & Accepted \\
\hline H4 & $\begin{array}{l}\text { IBT of shoppers significantly influences urge to } * * * \\
\text { buy impulsively. }\end{array}$ & Positive & Accepted \\
\hline H5 & $\begin{array}{l}\text { IBT of shopper is positively associated with } \\
\text { impulsive purchasing. }\end{array}$ & Positive & Rejected \\
\hline H6 & Gender of the respondents will influence IBT. & .022 & Negative & Rejected \\
\hline H7 & Income of the respondents will influence IBT & .857 & Negative & Rejected \\
\hline H8 & $\begin{array}{l}\text { Shoppers urge to buy impulsively has a } \\
\text { significant positive impact on impulse buying. }\end{array}$ & & Positive & Rejected \\
\hline
\end{tabular}

\section{Discussion}

Analysis of the model through SEM showed a good fit between the model and data. Three of the stated hypotheses were accepted while remaining five hypotheses were rejected. The results of this study reveal the fact that impulse buying is influenced by impulsive personality trait through IBT and urge.

The research framework developed by Beatty and Ferrell (1998) considered and explained impulse buying behavior. However, their work didn't take into account the effect of store variables. In the same line Mohan, Sivakumaran, and Sharma (2013) extended Beatty and Ferrell study (1998) by adding "urge to buy" as a new construct. It established the positive relationship between store environments and urges to buy. Various other studies have identified the need of incorporating store level variables as most of the impulsive decisions are taken inside a store (Peck \& Childers, 2006; Zhou \& Wong, 2004). Many western studies have found that most consumer decisions at the point of purchase are impulsive (Dawson \& Kim, 2010; Heilman, Nakamoto, \& Rao, 2002). Hence, by extending Mohan, Sivakumaran, and Sharma (2013), the paper significantly adds to the existing body of knowledge on impulsive shopping, by addressing the above-stated gap. This study is unique and pioneer in examining the combined effect of various store environment cues (i.e. sound, well-lit, layout, and sales representative, crowd, display, aroma) and impulsive buying personality traits along with IBT and urge to buy impulsively on impulsive shopping behavior. Previous researchers have taken into account different retail environment cues individually on the consumers' decision making behavior. In contrary, this study pioneered by developing an impulse buying framework incorporating characteristics related to shoppers' impulsive personality as well as store environment. As in case of study by Mohan, Sivakumaran, and Sharma (2013), store environment is taken as a formative one in this research model too. 
Gender differences are noticeably visible in the domain of consumer behavior specifically impulse buying. Few of the prominent studies observed that males tend to buy less frequently than females (Dittmar, Beattie, \& Friese, 1995, 1996; Wood, 1998). The findings from this study are quite contrary to those of many other studies. The results suggested that there was no significant gender difference on IBT. Also, in line with previous research, income was found to have no effect on impulse buying (Kollat \& Willett, 1967). The findings from the present research cemented this (no significant income difference was found on IBT). Similarly, association between impulsive buying personality and IBT is observed to be stronger; this indicates that personality traits are more important in determining the impulse tendency than income or gender. Finding from our study strongly suggests that the tendency of impulsive shopping is ingrained in personality. The results also reveal that IBT significantly influences impulse buying. This in turn shows that as shoppers' IBT escalates the occurrence of their impulsiveness increases. This finding is in line with the work of Rook and Fisher (1995), which highlighted the importance of IBT in identifying consumers' impulse buying behavior. Similarly, we find that urge to buy affects impulse buying behavior. As consumer feel more urge to buy, impulse buying increases. This finding is in line with Beatty and Ferrell (1998) and Mohan, Sivakumaran, and Sharma (2013) who show that consumer urge to buy influences impulse buying. Similarly, association between impulsive buying personality and IBT is observed to be stronger; this indicates that personality traits are more important in determining the impulse tendency than income or gender. Finding from our study strongly suggests that the tendency of impulsive shopping is ingrained in personality. The store-environment has negative and insignificant effect on impulse buying tendency in Pakistan's region, whereas impulsive personality traits and impulse buying tendency have significant effects. However gender and income have no significant impact on impulse buying tendency, while urge and impulse buying tendency has significant effect. However urge has no impact on impulse buying. Impulse buying tendency has no significant effect on impulse buying while there is a significant effect of impulsive personality traits on impulse buying.

\subsection{Managerial Implication and Significance}

This study confirmed the role of personality in encouraging impulse buying at retail outlets. The specific dimension, which have portrayed positive correlation with impulse buying are impulsive personality traits, urge to buy impulsively and impulse buying tendency. This study is devised in such a manner that it explores the underlying dynamics of impulsive personality traits and store environment on impulse buying of consumer. This study combines the store environment and impulsive personality traits and their effect on impulse buying behavior In Pakistan's region. The study also proposes the positive impact of store environment on impulsive buying tendency that leads to urge to buy and finally impulsive purchase. The study also help marketers should identify ways to reach out open ended and extrovert people to target their promotional offers. This study will also help researchers and marketers to know the buying behavior of Pakistani people related to the people of developed countries.

\section{Conclusion}

The basic purpose of this study is to determine the influence of impulsive personality traits and store environment on impulse buying of consumer in Pakistan's region. Many studies have concluded that sound or background music plays an important role in retail chain environment that impacts the purchasers' desire to connect in buyer-seller interactions. Other store environmental attributes like smell/ aroma have also been supposed to effect purchasing performance (Beverland et al., 2006; Chebat, Chebat, \& Vaillant, 2001). All these signs of the store create an impactful positive relationship with impulse buying. While Verplanken and Herabadi (2001) exhibited that cognitive aspects of shoppers were associated with low need to evaluate, and a lack of conscientiousness. The sudden and immediate or lack of planning while, purchasing products are few of the characteristics of impulse buyers influencing their impulse buying tendency. Most of the researchers also concluded that shoppers counting high on impulse buying tendency express more urges to buy and encourage impulsive purchase (Beatty \& Ferrell, 1998; Dawson \& Kim, 2009; Mohan, Sivakumaran, \& Sharma, 2013). It is also concluded that impulse buying tendency creates impulse buying. There is a conflict of finding in the relationship between gender and impulse purchasing; few studies suggest that women are more impulsive than men (Dittmar, Beattie, \& Friese, 1995). A study by Cobb and Hoyer (1986) established that men show more impulsive buying tendency than women. In contrast, Verplanken and Herabadi (2001) reveal that IBT is not correlated with gender. Previous studies on impulsive shopping suggest that it's hard to control the urges during physical closeness of the product, while attractive display also creates urge to buy more (Dholakia, 2000; Baumeister, 2002; Beatty \& Ferrell, 1998; Mohan, Sivakumaran, \& Sharma, 2013; Rook, 1987).

The results have shown that holistically speaking, that impulsive personality trait and urge to buy are positively correlated with the impulse buying and impulse buying tendency. The p value for store environment is 0.051 which 
is not less than 0.05 , thus, store environment has insignificant impact on impulse buying tendency. For the path "impulsive personality traits", $\mathrm{p}$ value is 0.001 which shows significant relationship between impulsive personality traits and impulse buying tendency. For the gender, $p$ value is .022 which is less than 0.05 but the beta-coefficient is negative so reject the influence of gender on impulse buying tendency and thus showing insignificant relationship. However, the $\mathrm{p}$ value for income and impulse buying tendency is .857 which is more than 0.05 , thus, this indicates insignificant relationship. The relationship between urge and impulse buying tendency is too significant as $\mathrm{p}$ value is 0.000 which is too less than 0.05 . Whereas, urge and impulse buying shows insignificant relationship as $\mathrm{p}$ value exceeds 0.05 . However impulse buying tendency and impulse buying also show insignificant relationship as $p$ value is 0.073 , while impulsive personality trait and impulse buying shows significant relationship with $\mathrm{p}$ value .038 . The estimates show that impulsive personality trait and urge to buy are positively correlated with the impulse buying and impulse buying tendency. However, certain factors have been found to be insignificantly associated with impulse buying and impulse buying tendency; for example, store environment, , income and gender are found to be insignificantly associated with the impulse buying tendency. However, the rest independent variables, like impulsive personality trait is found to be significantly associated with the impulse buying and impulse buying tendency. It should be noted that impulsive personality trait, urge to buy and impulse buying tendency is found to have more positively correlated impact than store-environment, gender and income.

This study confirmed the role of personality in encouraging impulse buying at retail outlets. Marketers should identify ways to reach out open ended and extrovert people to target their promotional offers. The gap is somehow covered in this research by the result in a way that personality has greater impact on impulse buying of consumers so that marketer use following parameters or technique in-store and out of store to target the extrovert people or people who have tendency to buy for their goods and services.

\subsection{Limitation}

Every research is characterized by limitations, which define the boundary for its finding and its generalizability. The prominent limitation of this paper is the population from which the sample has been selected. The data pertains to only one emerging market Karachi Pakistan, therefore the findings of this paper may not be representative of young shoppers across the world. Hence, similar research could include data from customer groups from different emerging and developed economies.

This will examine the validity and reliability of the finding. Also, the data was collected for the study from various types of retail environments and formats like grocery stores, super markets, departmental stores, shopping malls and company owned outlets. Further studies may assess the extent to which the impulsive behavior differs across different retail environments.

\subsection{Future Direction}

The future studies should explore the experimentation methodologies as works in quantitative designs are frequent. Furthermore, hands-on knowledge can be provided in this regard via employing market experimentation techniques. Given the fact that this study has negated certain aspects of Impulsive personality traits and store environment along with IBT, urge to buy, impulse buying and thus, there is a great room to explore various other variables in this regard. Similar research could include data from customer groups from different emerging and developed economies. This will examine the validity and reliability of the finding

\section{References}

Abratt, R., Goodey, J. A., \& Stephen, D. (1990). Unplanned buying and in-store stimuli in supermarkets. Journal of Managerial \&Decision Economics, 11(2), 111-121. http://dx.doi.org/10.1002/mde.4090110204

Akram, U., Hui, P., Khan, M. K., Hashim, M., \& Rasheed, S. (2016). Impact of store atmosphere on impulse buying behavior: Moderating effect of demographic variables. International Journal of u-and Service, Science and Technology, 9(7), 43-60.

Anderson, J. C., \& Gerbing, D. W. (1988). Structural equation modeling in practice: A review and recommended two-step approach. Psychological Bulletin, 103(3), 411-423.

Andreassen, C. S., Griffiths, M. D., Gjertsen, S. R., Krossbakken, E., Kvam, S., \& Pallesen, S. (2013). The relationships between behavioral addictions and the five-factor model of personality. Journal of Behavioral Addictions, 2(2), 90-99. https://doi.org/10.1556/JBA.2.2013.003

Anić, I., \& Radas, S. (2006). The impact of situational factors on purchasing outcomes in the Croatian hypermarket retailer. Ekonomski Pregled, 57(11), 730-752. 
Areni, C. S., \& Kim, D. (1994). The influence of in-store lighting on consumers examination of merchandise in a wine store. International Journal of Research in Marketing, 11, 117-125. http://dx.doi.org/10.1016/0167-8116(94)90023-X

Babin, B. J., \& Attaway, J. S. (2000). Atmospheric affect as a tool for creating value and gaining share of customer. Journal of Business Research, 49(2), 91-99.

Babin, B. J., \& Kim, K. (2001). International students' travel behavior: A model of the travel-related consumer/dissatisfaction process. Journal of Travel \& Tourism Marketing, 10(1), 93-106.

Baker, J., Parasuraman, A., Grewal, D., \& Voss, G. B. (2002). The influence of multiple store environment cues on perceived merchandise value and patronage intentions. Journal of Marketing, 66(2), 120-141. http://dx.doi.org/10.1509/jmkg.66.2.120.18470.

Baumeister, R. F. (2002). Yielding to temptation: self-control failure, impulsive purchasing, and consumer behavior. Journal of Consumer Research, 28(4), 670-676.

Beatty, S. E., \& Ferrell, M. E. (1998). Impulse buying: modeling its precursors. Journal of Retailing 74(2), 169-191.

Bellenger, D. N., Robertson, D. H., \& Hirschman, E. C. (1978). Impulse buying varies by product. Journal of Advertising Research, 18(6), 15-18.

Bellizzi, J. A., Crowley, A. E., \& Hasty, R. W. (1983). The effects of color in store design. Journal of Retailing, 59(1), 21-47.

Beverland, M., Lim, E. A. C., Morrison, M., \& Terziovski, M. (2006). In-store music and consumer-brand relationships: Relational transformation following experiences of (mis) fit. Journal of Business Research, 59(9), 982-989.

Bohl, P. (2012). The effects of store atmosphere on shopping behavior: a literature review. Corvinus Marketing Tanulmányok.

Bozionelos, N. (2004). The big five of personality and work involvement. Journal of Managerial Psychology, 19(1), 69-81. https://doi.org/10.1108/02683940410520664

Chang, H. J., Eckman, M., \& Yan, R. N. (2011). Application of the Stimulus-Organism-Response model to the retail environment: the role of hedonic motivation in impulse buying behavior. The International Review of Retail, Distribution and Consumer Research, 21(3), 233-249. http://dx.doi.org/10.1080/09593969.2011.578798

Chebat, J. C., \& Michon, R. (2003). Impact of ambient odors on mall shoppers' emotions, cognition, and spending: A test of competitive causal theories. Journal of Business Research, 56(7), 529-539.

Chebat, J. C., Chebat, C. G., \& Vaillant, D. (2001). Environmental background music and in-store selling. Journal of Business Research, 54(2), 115-123.

CNBC. (2009). Coca-cola: the real story behind the real thing. Retrieved January 22, 2016, from https://www.youtube.com/watch?v=vPjg5lBOcu

Cobb, C. J., \& Hoyer, W. D. (1986). Planned versus impulse purchase behavior. Journal of Retailing, 64(4), 384-409.

Cooper, D. R., \& Schindler, P. S. (2008). Business research methods (International 2nd ed.). Singapore: McGraw-Hill Education. Handbook of Data Analysis. New York: Sage.

Crowley, A. E. (1993). The two-dimensional impact of color on shopping. Marketing Letters, 4(1), 59-69. http://dx.doi.org/10.1007/BF00994188.

Dawson, S., \& Kim, M. (2009). External and internal trigger cues of impulse buying online. Direct Marketing: An International Journal, 3(1), 20-34. http://dx.doi.org/10.1108/17505930910945714

Dawson, S., \& Kim, M. (2010). Cues on apparel web sites that trigger impulse purchases. Journal of Fashion Marketing and Management: An International Journal, 14(2), 230-246.

Dholakia, U. M. (2000). Temptation and resistance: an integrated model of consumption impulse formation and enactment. Psychology and Marketing, 17(11), 955-982.

Dittmar, H., Beattie, J., \& Friese, S. (1995). Gender identity and material symbols: Objects and decision considerations in impulse purchases. Journal of Economic Psychology, 16(3). 
Donnelly, G., Iyer, R., \& Howell, R. T. (2012). The Big Five personality traits, material values, and financial well-being of self-described money managers. Journal of Economic Psychology, 33(6), 1129-1142. https://doi.org/10.1016/j.joep.2012.08.001

Farid, D. S., \& Ali, M. (2018). Effects of Personality on Impulsive Buying Behavior: Evidence from a Developing Country. Marketing and Branding Research, 5(1), 31-43.

Feldman, R. S. (2010). Psychology and your life. Boston: McGraw/Hill. Retrieved from http://www.worldcat.org/title/psychology-and-your-life/oclc/271104603

Foroughi, A., Buang, N. A., \& Sadeghi, R. H. M. (2012). Exploring the influence of situational factors (money\& time available) on impulse buying behavior among different ethics. International Journal of Fundamental Psychology \& Social Sciences, 2(2), 41-44.

Gillet, N., Fouquereau, E., Forest, J., Brunault, P., \& Colombat, P. (2012). The impact of organizational factors on psychological needs and their relations with well-being. Journal of Business and Psychology, 27(4), 437-450.

Haberland, M. F. (2010). The power of scent: Empirical field studies of olfactory cues on purchase behavior. Doctoral dissertation, University of St. Gallen.

Hair, J. F., Black, W. C., Babin, B. J., Anderson, R. E., \& Tatham, R. L. (2006). Multivariate data analysis, Vol. 6. Pearson Prentice Hall, Upper Saddle River NJ.

Heilman, C. M., Nakamoto, K., \& Rao, A. G. (2002). Pleasant surprises: Consumer response to unexpected in-store coupons. Journal of Marketing Research, 39(2), 242-252. http://dx.doi.org/10.1509/jmkr.39.2.242.19081

Herrington, J. D. (1996). Effects of music in service environments: a field study. Journal of Services Marketing, 10(2), 26-41. http://dx.doi.org/10.1108/08876049610114249.

Hirsh, J. B. (2010). Personality and environmental concern. Journal of Environmental Psychology, 30(2), 245-248. https://doi.org/10.1016/j.jenvp.2010.01.004.

Hogan, J., Barrett, P., \& Hogan, R. (2007). Personality measurement, faking, and employment selection. Journal of Applied Psychology, 92(5), 1270-1285. https://doi.org/10.1037/0021-9010.92.5.1270.

Holbrook, M. B., \& Anand, P. (1990). Effects of tempo and situational arousal on the listeners. http://dx.doi.org/10.1016/S0148-2963(97)00122-7

Hough, L. M., Eaton, N. K., Dunnette, M. D., Kamp, J. D., \& McCloy, R. A. (1990). Criterion related validities of personality constructs and the effect of response distortion on those validities. Journal of Applied Psychology, 75(5), 581-595. https://doi.org/10.1037/0021-9010.75.5.581

Hulte'n, P., \& Vanyushyn, V. (2011) Impulse purchases of groceries in France and Sweden. Journal of Consumer Marketing, 28(5), 376-384. http://dx.doi.org/10.1108/07363761111150026

Hussain, R., \& Ali, M. (2015). Effect of Store Atmosphere on Consumer Purchase Intention. International Journal of Marketing Studies, 7(2).

Hussain, R., \& Ali, M. (2015, April). Effect of Store Atmosphere on Consumer Purchase Intention. International Journal of Marketing Studies, 7, 35. https://doi.org/10.5539/ijms.v7n2p35

Jamal, M., \& Lodhi, S. (2015). Consumer shopping behavior in relation to factors influencing impulse buying: A case of superstores in Karachi, Pakistan. International Journal of Scientific and Research Publications, 5(2), 41.

John, O. P., \& Srivastava, S. (1999). The Big Five trait taxonomy: History, measurement, and theoretical perspectives. Handbook of Personality: Theory and Research, 2, 102-138.

Jones, M. A. (1999). Entertaining shopping experiences: an exploratory investigation. Journal of Retailing and Consumer Services, 6(3), 129-139.

Jones, M. A., Reynolds, K. E., Weun, S., \& Beatty, S. E. (2003). The product-specific nature of impulse buying tendency. Journal of Business Research, 56(7), 505-511.

Kacen, J. J., \& Lee, J. A. (2002). The Influence of Culture on Consumer Impulsive Buying Behavior. Journal of Consumer Psychology, 12(2), 163-176.

Khan, N., Hui, L. H., Chen, T. B., \& Hoe, H. Y. (2015). Impulse buying behaviour of generation Y in fashion retail. International Journal of Business and Management, 11(1), 144. 
Kollat, D. T., \& Willett, R. P. (1967). Customer impulse purchasing behavior. Journal of Marketing Research, 21-31.

Kotler, P. (1973). Atmospherics as a marketing tool. Journal of Retailing, 49(4), 48-64.

KPMG. (2014). India luxury summit $2014 . \quad$ Retrieved from https://www.kpmg.com/IN/en/IssuesAndInsights/ArticlesPublications/Documents/KPMG-ASSOCHAM-IndiaLuxury-Summit-2014.pdf

Lam, S. Y. (2001). The effects of store environment on shopping behaviors: A critical review. Advances in Consumer Research, 28, 190-197.

Larsen, R., Cervone, D., \& Butterworth, J. (2010). Personality psychology: domains of knowledge about human. Info: New York: McGraw-Hill Retrieved from http://sunway.edu.my/jb/images/library/NewArrival_Book_20160401.pdf

Leong, L. Y., Jaafar, N. I., \& Sulaiman, A. (2017). Understanding Impulse Purchase in Facebook Commerce: Does Big Five Matter?. Internet Research.

Liu, Y., Li, H., \& Hu, F. (2013). Website attributes in urging online impulse purchase: An empirical investigation on consumer perceptions. Decision Support Systems, 55(3), 829-837. https://doi.org/10.1016/j.dss.2013.04.001

Luo, X. (2004). Group dynamics of impulse buying: An extended social facilitation perspective. ACR North American Advances.

Luo, X. (2005). How does shopping with others influence impulsive purchasing?. Journal of Consumer Psychology, 15(4), 288-294.

Mattila, A. S., \& Wirtz, J. (2008). The role of store environmental stimulation and social factors on impulse purchasing. Journal of Services Marketing, 22(7), 562-567. http://dx.doi.org/10.1108/08876040810909686

McCrae, R. R., \& Costa, P. T. (2008). Empirical and theoretical status of the five-factor model of personality traits. The SAGE Handbook of Personality Theory and Assessment, 1, 273-294.

Mehrabian, A. (1976). Public Spaces and Private Spaces: The Psychology of Work, Play and Living Environments. New York: Basic Books, Inc.

Mick, D. G., \& DeMoss, M. (1990). Self-gifts: Phenomenological insights from four contexts. Journal of Consumer Research, 17, 322-332.

Milliman, R. E. (1986). The influence of background music on the behaviour of restaurant patrons. The Journal of Consumer Research, 13(2), 286-289. http://dx.doi.org/10.1086/209068

Mills, K. H., Paul, J. E., \& Moorman, K. B. (1995). Apparel visual merchandising (3rd ed.). Englewood Cliffs, NJ: Prentice-Hall.

Mohan, G., Sivakumaran, B., \& Sharma, P. (2013). Impact of store environment on impulse buying behavior. European Journal of Marketing, 47(10), 1711-1732. http://dx.doi.org/10.1108/EJM-03-2011-0110

Mondak, J. J. (2010). Personality and the foundations of political behavior. Cambridge University Press.

Mooradian, T. A., \& Swan, K. S. (2006). Personality-and-culture: The case of national extraversion and word-of-mouth. Journal of Business Research, 59(6), 778-785. https://doi.org/10.1016/j.jbusres.2006.01.015

Neuman, W. L. (2013). Social research methods: Qualitative and quantitative approaches.

Newman, A. J., \& Patel, D. (2004). The marketing directions of two fashion retailers. European Journal of Marketing, 38(7), 770-789.

Nicholls, J. A. (1997). Time and companionship: Key factors in Hispanic shopping behavior. Journal of Consumer Marketing, 14(3), 194-205.

Nor, A. O., Ruzita, A. R., Che, A. C. W., \& Syer, S. A. (2014). Compulsive buying and credit card misuse among credit card holders: The roles of self-esteem, materialism, impulsive buying and budget constraint. Intangible Capital, 10(1), 52-74.

Nunnally, J. (1978). Psychometric methods. New York: McGraw-Hill.

Parboteeah, D. V. (2005). A model of online impulse buying: An empirical study. Doctoral dissertation, Washington State University. 
Park, J., \& Lennon, S. J. (2006). Psychological and environmental antecedents of impulse buying tendency in the multichannel shopping context. Journal of Consumer Marketing, 23(2), 56-66. http://dx.doi.org/10.1108/07363760610654998

Peck, J., \& Childers, T. L. (2006). If I touch it I have to have it: Individual and environmental influences on impulse purchasing. Journal of Business Research, 59(6), 765-769.

POPAI. (2012). The 2012 Shopper Engagement Study. Point-of-Purchase Advertising International. Retrieved January 22, 2016, from http://www.popai.com/engage/docs/Media-Topline-Final.pdf

Prashar, S., Parsad, C., \& Vijay, T. S. (2015). Factors prompting impulse buying behavior study among shoppers in India. International Journal of Indian Culture and Business Management, 11(2), 219-244. http://dx.doi.org/10.1504/IJICBM.2015.071308

Roberts, B. W., Lejuez, C., Krueger, R. F., Richards, J. M., \& Hill, P. L. (2014). What is conscientiousness and how can it be assessed?. Developmental Psychology, 50(5), 1315-1330. https://doi.org/10.1037/a0031109

Roberts, J. A., Pullig, C., \& Manolis, C. (2015). I need my smartphone: A hierarchical model of personality and cell-phone addiction. Personality and Individual Differences, 79, 13-19. https://doi.org/10.1016/j.paid.2015.01.049

Rook, D. W. (1987). The buying impulse. Journal of Consumer Research, 14(2), 189-199.

Rook, D. W., \& Fisher, R. J. (1995). Normative influences on impulsive buying behavior. Journal of Consumer Research, 22(3), 305-313.

Rook, D. W., \& Gardner, M. P. (1993). In the mood: impulse buying's affective antecedents. Research in Consumer Behavior, 6(7), 1-28.

Russell, J. A., \& Mehrabian, A. (1978). Approach-avoidance and affiliation as functions of the emotion-eliciting quality of an environment. Environment and Behavior, 10(3), 355-387. http://dx.doi.org/10.1177/0013916578103005

Saad, M., \& Metawie, M. (2015). Store environment, personality factors and impulse buying behavior in Egypt: The mediating roles of shop enjoyment and impulse buying tendencies. Journal of Business and Management Sciences, 3(2), 69-77.

Schiffman, L., \& Kanuk, L. L. (2008). Consumer Behaviour (7th ed.). Jakarta: PT. Indeks.

Shahjehan, A., Qureshi, J. A., Zeb, F., \& Saifullah, K. (2012). The effect of personality on impulsive and compulsive buying behaviors. African Journal of Business Management, 6(6), 2187-2194. https://doi.org/10.5897/AJBM11.2275

Silva, T. S., \& Giraldi, J. D. M. E. (2010). The influence of store image on customer satisfaction: a case study of a shoe store. Brazilian Business Review, 7(2), 60-77. http://dx.doi.org/10.15728/bbr.2010.7.2.4

Siorowska, A. G. (2011). Gender as a moderator of temperamental causes of impulse buying tendency. Journal of Consumer Research, 10(2), 119-142.

Spies, K., Hesse, F., \& Loesch, K. (1997). Store atmosphere, mood and purchasing behavior. International Journal of Research in Marketing, 14(1), 1-17.

Srinivasan, S. R., \& Srivastava, R. K. (2010). Creating the futuristic retail experience through experiential marketing: Is it possible quest; an exploratory study. Journal of Retail \& Leisure Property, 9(3), 193-199. http://dx.doi.org/10.1057/rlp.2010.12

Stern, H. (1962). The significance of impulse buying today. The Journal of Marketing, 59-62.

Thompson, E. R., \& Prendergast, G. P. (2015). The influence of trait affect and the five-factor personality model on impulse buying. Personality and Individual Differences, 76, 216-221.

Turley, L. W., \& Milliman, R. E. (2000). Atmospheric affects on shopping behaviour a review of the experimental. Journal of Business Research, 49, 193-211. http://dx.doi.org/10.1016/S0148-2963(99)00010-7

Underhill, P. (2009). Why we buy: The science of shopping-Updated and revised for the internet, the global consumer, and beyond. New York, NY: Simon and Schuster.

Verplanken, B., \& Herabadi, A. (2001). Individual differences in impulse buying tendency: Feeling and no thinking. European Journal of Personality, 15(S1), S71-S83. 
Virvalaite, R., Saladiene, V., \& Bagdonaite, R. (2009). Peculiarities of impulsive purchasing in the market of consumer goods. Engineering Economics, 62(2).

Vohs, K., \& Faber, R. (2007). Self-regulation and impulsive spending patterns. Advances in Consumer Research, 30,125-126.

Wakefield, K. L., \& Baker, J. (1998). Excitement at the mall: determinants and effects on shopping response. Journal of Retailing, 74(4), 515-539. http://dx.doi.org/10.1016/S0022-4359(99)80106-7

Ward, J. C., Bitner, M. J., \& Barnes, J. (1992). Measuring the prototypicality and meaning of retail environments. Journal of Retailing.

Watson, D., \& Clark, L. A. (1991). Self- versus peer ratings of specific emotional traits: Evidence of convergent and discriminant validity. Journal of Personality and Social Psychology, 60(6), 927-940. https://doi.org/10.1037/0022-3514.60.6.927

Weinberg, P., \& Gottwald, W. (1982) Impulsive consumer buying as a result of emotions. Journal of Business Research, 10(1), 43-57.

Wood, M. (1998). Socio-economic status, delay of gratification, and impulse buying. Journal of Economic Psychology, 19(3), 295-320.

Wu, J. J., Chen, Y. H., \& Chien, S. H. (2013). Impulse purchases and trust: the mediating effect of stickiness and the mental budgeting account. Cyberpsychology, Behavior, and Social Networking, 16(10), 767-773.

Xiao, S. H., \& Nicholson, M. (2011). Mapping impulse buying: a behaviour analysis framework for services marketing and consumer research. The Service Industries Journal, 31(15), 2515-2528.

$\mathrm{Xu}, \mathrm{Y}$. (2007). Impact of store environment on adult generation Y consumers' impulse buying. Journal of Shopping Center Research, 14(1), 39-56.

Yalch, R. F., \& Spangenberg, E. R. (2000). The Effects of Music in a Retail Setting on Real and Perceived Shopping Times. Journal of Business Research, 49(2), 139-147. http://dx.doi.org/10.1016/S0148-2963(99)00003-X

Yoo, C., Park, J., \& MacInnis, D. J. (1998). Effects of Store Characteristics and In-Store Emotional Experiences on Store Attitude. Journal of Business Research, 42(3), 253-263. http://dx.doi.org/10.1016/S0148-2963(97)00122-7

Youn, S., \& Faber, R. J. (2000). Impulse Buying: Its Relation to Personality Traits and Cues. ACR North American Advances, NA-27. Retrieved from $\mathrm{http}: / / \mathrm{www}$.acrwebsite.org/search/view-conference-proceedings.aspx $? \mathrm{Id}=8383$

Yu, C., \& Bastin, M. (2010). Hedonic shopping value and impulse buying behavior in transitional economies: A symbiosis in the Mainland China marketplace. Journal of Brand Management, 18(2), 105-114.

Yüksel, A. (2009). Exterior Color and Perceived Retail Crowding: Effects on Tourists' Shopping Quality Inferences and Approach Behaviors. Journal of Quality Assurance in Hospitality \& Tourism, 10(4), 233-254. http://dx.doi.org/10.1080/15280080903183383

Yun, Z. S., \& Good, L. K. (2007). Developing customer loyalty from e-tail store image attributes. Managing Service Quality, 17(1), 4-22. http://dx.doi.org/10.1108/09604520710720647

Zeynep, E., \& Nilgun, G. (2011). Congruence between atmospheric cues and store image in fashion retailing. Turkey: Izmir University of Economics.

Zhou, H., \& Gu, Z. (2015). The Effect of Different Price Presentations on Consumer Impulse buying. http://dx.doi.org/10.4236/ajibm.2015.51004

Zhou, L., \& Wong, A. (2004). Consumer impulse buying and in-store stimuli in Chinese supermarkets. Journal of International Consumer Marketing, 16(2), 37-53. 